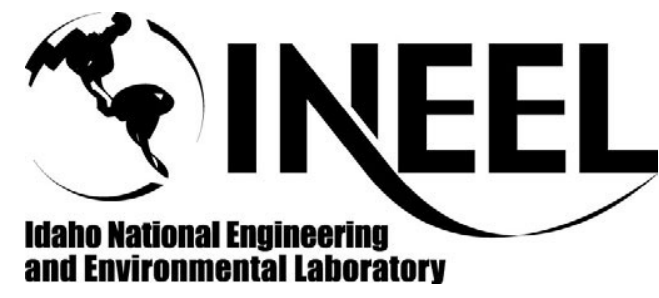

INEEL/CON-01-00939

PREPRINT

Multi-Megawatt Power System Trade Study

Glen R. Longhurst

Bruce G. Schnitzler

Benjamin T. Parks

February 3, 2002

Space Technology And Applications International Forum (STAIF 2002)

This is a preprint of a paper intended for publication in a journal or proceedings. Since changes may be made before publication, this preprint should not be cited or reproduced without permission of the author.

This document was prepared as an account of work sponsored by an agency of the United States Government. Neither the United States Government nor any agency thereof, or any of their employees, makes any warranty, expressed or implied, or assumes any legal liability or responsibility for any third party's use, or the results of such use, of any information, apparatus, product or process disclosed in this report, or represents that its use by such third party would not infringe privately owned rights. The views expressed in this paper are not necessarily those of the U.S. Government or the sponsoring agency. 


\title{
Multi-Megawatt Power System Trade Study
}

\author{
Glen R. Longhurst ${ }^{1}$, Bruce G. Schnitzler ${ }^{1}$, and Benjamin T. Parks ${ }^{2}$ \\ ${ }^{1}$ Idaho National Engineering and Environmental Laboratory \\ P.O. Box 1625, Idaho Falls, Idaho 83415-3860 \\ ${ }^{2}$ Worcester Polytechnic Institute, 100 Institute Road, Worcester, MA 01609-2280 \\ Glen R. Longhurst: (208) 526-9950,gxl@inel.gov
}

\begin{abstract}
A concept study was undertaken to evaluate potential multi-megawatt power sources for nuclear electric propulsion. The nominal electric power requirement was set at $15 \mathrm{MW}_{\mathrm{e}}$ with an assumed mission profile of 120 days at full power, 60 days in hot standby, and another 120 days of full power, repeated several times for 7 years of service. Two configurations examined were (1) a gas-cooled reactor based on the NERVA Derivative design, operating a closed cycle Brayton power conversion system; and (2) a molten metal-cooled reactor based on SP-100 technology, driving a boiling potassium Rankine power conversion system. This study considered the relative merits of these two systems, seeking to optimize the specific mass. Conclusions were that either concept appeared capable of approaching the specific mass goal of 3-5 $\mathrm{kg} / \mathrm{kW}_{\mathrm{e}}$ estimated to be needed for this class of mission, though neither could be realized without substantial development in reactor fuels technology, thermal radiator mass efficiency, and power conversion and distribution electronics systems capable of operating at high temperatures. The gas-Brayton systems showed an apparent specific mass advantage ( $3.53 \mathrm{vs} 6.43 \mathrm{~kg} / \mathrm{kW}_{\mathrm{e}}$ for the baseline cases) under the set of assumptions used, but reconciling differences in conservatism in the design algorithms used would make results much more comparable. Brayton systems eliminate the need to deal with two-phase working fluid flows in the microgravity environment of space.
\end{abstract}

\section{INTRODUCTION}

Nuclear power at the multi-megawatt level will provide a benefit to future space missions. As part of the Special Purpose Fission Technology (SPFT) program conducted by the U. S. Department of Energy's Office of Nuclear Energy, Science and Technology (DOE-NE), an initial concept trade study was undertaken by the INEEL to evaluate feasibility, on the basis of specific mass, of two configurations of space nuclear power systems, subject to a set of operational constraints (Longhurst, 2001c).

A target specific mass of 3-5 kg/kWe was set for the power system. Operational specifications for this design included a design lifetime of seven calendar years; a nominal electric power requirement of $15 \mathrm{MW}_{\mathrm{e}}$ compatible with the Variable Specific Impulse Magnetoplasma Rocket (VASIMR) engine concept (Chang-Díaz, 2000), and an assumed mission profile of 120 days at full power, 60 days in hot standby, and another 120 days of full power, repeated several times.

\section{CONCEPT TRADE STUDY SET}

Two classes of power systems were selected for consideration. One uses a liquid-metal-cooled reactor and a metal vapor Rankine cycle power conversion system. The other uses Brayton cycle power conversion, but includes both gas-cooled and liquid-metal-cooled reactors (Longhurst, 2001c). In each case, two levels of availability were assumed regarding reactor fuel technology. The first was relatively state-of-the-art technology (which still may require considerable work to achieve), while the second was a "growth" or advanced technology. A listing of the major characteristics of the systems examined is in Table 1. 
TABLE 1. Concept Trade Study Set Developed for Multi-Megawatt Power System.

\begin{tabular}{|c|c|c|c|c|c|c|c|}
\hline Concept & Fuel & $\begin{array}{c}\text { Clad/ } \\
\text { Coating }\end{array}$ & $\begin{array}{c}\text { Neutron } \\
\text { Spectrum }\end{array}$ & $\begin{array}{l}\text { Reactor } \\
\text { Coolant }\end{array}$ & $\begin{array}{l}\text { Coolant } \\
\text { Outlet } \\
\text { Temp (K) } \\
\end{array}$ & $\begin{array}{c}\text { Power } \\
\text { Conversion }\end{array}$ & $\begin{array}{c}\text { Technology } \\
\text { Base }\end{array}$ \\
\hline \multicolumn{8}{|l|}{ Rankine: } \\
\hline $\mathrm{UN} / \mathrm{Nb}-1 \mathrm{Zr} / \mathrm{Li}-\mathrm{K}$ & $\mathrm{UN}$ & $\mathrm{Nb}-1 \mathrm{Zr}$ & Fast & $\mathrm{Li}$ & 1,350 & K-Rankine & SP-100 \\
\hline $\mathrm{UN} / \mathrm{Nb}-1 \mathrm{Zr} / \mathrm{Ga}-\mathrm{K}$ & $\mathrm{UN}$ & $\mathrm{Nb}-1 \mathrm{Zr}$ & Fast & $\mathrm{Ga}$ & 1,350 & K-Rankine & SP-100 \\
\hline $\mathrm{UN} / \mathrm{Nb}-1 \mathrm{Zr} / \mathrm{Li}-\mathrm{Na}$ & $\mathrm{UN}$ & $\mathrm{Nb}-1 \mathrm{Zr}$ & Fast & $\mathrm{Li}$ & 1,350 & $\begin{array}{c}\text { Na- } \\
\text { Rankine }\end{array}$ & SP-100 \\
\hline $\mathrm{UN} / \mathrm{Nb}-1 \mathrm{Zr} / \mathrm{Ga}-\mathrm{Na}$ & UN & $\mathrm{Nb}-1 \mathrm{Zr}$ & Fast & $\mathrm{Ga}$ & 1,350 & $\begin{array}{c}\text { Na- } \\
\text { Rankine }\end{array}$ & SP-100 \\
\hline UN/ASTAR $811 \mathrm{C} / \mathrm{Li}-\mathrm{K}$ & $\mathrm{UN}$ & $\begin{array}{c}\text { ASTAR } \\
811 \mathrm{C}\end{array}$ & Fast & $\mathrm{Li}$ & 1,500 & K-Rankine & $\mathrm{SP}-100^{\mathrm{a}}$ \\
\hline UN/ASTAR 811C/Ga-K & UN & $\begin{array}{c}\text { ASTAR } \\
811 \mathrm{C}\end{array}$ & Fast & $\mathrm{Ga}$ & 1,500 & K-Rankine & SP- $100^{\mathrm{a}}$ \\
\hline UN/ASTAR 811C/Li-Na & $\mathrm{UN}$ & $\begin{array}{c}\text { ASTAR } \\
811 \mathrm{C}\end{array}$ & Fast & $\mathrm{Li}$ & 1,500 & $\begin{array}{c}\text { Na- } \\
\text { Rankine }\end{array}$ & $\mathrm{SP}-100^{\mathrm{a}}$ \\
\hline \multicolumn{8}{|l|}{ Brayton: } \\
\hline $\mathrm{UC}_{2} / \mathrm{NbC}$ & $\mathrm{UC}_{2}$ & $\mathrm{NbC}$ & Thermal & $\mathrm{He}-\mathrm{Xe}$ & 1,640 & $\begin{array}{l}\text { He-Xe } \\
\text { Brayton }\end{array}$ & $\begin{array}{l}\text { NERVA } \\
\text { Derivative }\end{array}$ \\
\hline $\mathrm{UC}_{2} / \mathrm{NbC} \mathrm{IHX}$ & $\mathrm{UC}_{2}$ & $\mathrm{NbC}$ & Thermal & $\mathrm{He}-\mathrm{Xe}$ & 1,640 & $\begin{array}{l}\text { Brayton } \\
\text { Indirect }\end{array}$ & $\begin{array}{l}\text { Intermediate } \\
\text { Heat Exchgr }\end{array}$ \\
\hline $\mathrm{UC}_{2} / \mathrm{ZrC}$ & $\mathrm{UC}_{2}$ & $\mathrm{ZrC}$ & Thermal & $\mathrm{He}-\mathrm{Xe}$ & 1,920 & $\begin{array}{l}\text { He-Xe } \\
\text { Brayton }\end{array}$ & $\begin{array}{l}\text { NERVA } \\
\text { Derivative }^{\mathrm{a}}\end{array}$ \\
\hline $\mathrm{UO}_{2} / \mathrm{SiC}$ & $\mathrm{UO}_{2}$ & $\mathrm{SiC}$ & Thermal & $\mathrm{He}-\mathrm{Xe}$ & 1,520 & $\begin{array}{l}\text { He-Xe } \\
\text { Brayton }\end{array}$ & $\begin{array}{c}\text { Commercial } \\
\text { HTGR }\end{array}$ \\
\hline $\mathrm{UO}_{2} / \mathrm{ZrC}$ & $\mathrm{UO}_{2}$ & $\mathrm{ZrC}$ & Thermal & $\mathrm{He}-\mathrm{Xe}$ & 2,100 & $\begin{array}{l}\text { He-Xe } \\
\text { Brayton }\end{array}$ & $\begin{array}{c}\text { Advanced } \\
\text { HTGR }\end{array}$ \\
\hline $\mathrm{UN} / \mathrm{Nb}-1 \mathrm{Zr} / \mathrm{Li}$ & UN & $\mathrm{Nb}-1 \mathrm{Zr}$ & Fast & $\mathrm{Li}$ & 1,350 & $\begin{array}{c}\text { He-Xe } \\
\text { Brayton }\end{array}$ & SP-100 \\
\hline
\end{tabular}

${ }^{\mathrm{a}}$ Growth Technology.

For liquid metal cooled reactors, the near-term technology was UN fuel in $\mathrm{Nb}-1 \mathrm{Zr}$ cladding with a reactor coolant exit temperature of 1,350 K, as called for in the SP-100 design (Rutger, 1992). The "growth" option assumed a cladding change to ASTAR $811 \mathrm{C}$, which is believed to allow a reactor coolant exit temperature of $1,500 \mathrm{~K}$.

For gas-cooled reactors, we chose as a reference the NERVA Derivative technology (Pierce, 1991). As a baseline, we chose $\mathrm{UC}_{2}$ (coated uranium carbide particles in a graphite matrix) fuel with $\mathrm{NbC}$ coating. This was assumed to have a gas exit temperature of $1,640 \mathrm{~K}$. "Growth" options included $\mathrm{UC}_{2}$ fuel with $\mathrm{ZrC}$ coating and $\mathrm{UO}_{2}$ with $\mathrm{SiC}$ and $\mathrm{ZrC}$ coatings. Reactor outlet temperatures assumed ranged from $1,520 \mathrm{~K}$ for the $\mathrm{UO}_{2} / \mathrm{SiC}$ option to $2,100 \mathrm{~K}$ for the $\mathrm{UO}_{2} / \mathrm{ZrC}$ option, though turbine inlet temperatures above $1,700 \mathrm{~K}$ are beyond present capabilities (General Electric, 2001a).

A final case considered was a liquid lithium-cooled reactor operating a Brayton system through a heat exchanger. It used $\mathrm{UN}$ fuel with $\mathrm{Nb}-1 \mathrm{Zr}$ cladding. Reactor outlet temperature for this system was $1,350 \mathrm{~K}$. 


\section{APPROACH}

We evaluated these concepts in terms of their specific masses, counting all the elements of the power system, including the reactor, shield, power conversion, power management and distribution (PMAD), and heat rejection systems.

Liquid-cooled reactor masses and masses of Rankine power conversion systems were estimated using ALKASYSM (Longhurst, 2001a), a modified version of the ALKASYS-PC code (Moyers, 1987). We modified ALKASYS-PC by adding flexibility to make use of other fluids than lithium and potassium as either primary coolant or working fluid, and to use an optional electric motor to operate the boiler feed pump in lieu of the vapor-driven turbine assumed in the code. The temperature at which structural material changed from $\mathrm{Nb}-1 \mathrm{Zr}$ to ASTAR $811 \mathrm{C}$ was also made arbitrary, and an option was added to allow blade tip velocity to be specified as a Mach number. Reactor structural materials assumed were $\mathrm{Nb}-1 \mathrm{Zr}$ for reactor temperatures less than $1360 \mathrm{~K}$, and the tantalum alloy ASTAR $811 \mathrm{C}$ above that. Fuel cladding is assumed in the code to be ASTAR $811 \mathrm{C}$ at all temperatures. The difference in overall reactor mass in accepting this assumption as compared with using $\mathrm{Nb}-1 \mathrm{Zr}$ density for the low-temperature cladding was inconsequential.

Gas-cooled reactor masses were based on the Enabler NERVA Derivative reactor design (Pierce, 1991) using a polynomial fit to interpolate mass estimates at $5,10,40$, and $70 \mathrm{MW}_{\mathrm{e}}$ to the $15 \mathrm{MW}_{\mathrm{e}}$ power used as a basis for comparison here. Scaling to different operating temperatures than 1,920 K given as the Enabler gas exit temperature was based on the assumptions that

1. Reactor overall mass density and configuration would remain essentially constant,

2. Reactor volume would increase as the $3 / 2$ power of flow areas required to carry thermal power,

3. Thermal power from the reactor would change with thermodynamic efficiency of the Brayton systems connected to them,

4. Flow velocities and gas pressures would remain constant.

Power conversion system analyses for the Brayton cases identified were performed at the NASA Glenn Research Center (GRC) (Mason, 2001).

Our basis for shield mass comparison for both cases was that used in the SP-100 study: a circular shielded area $4.5 \mathrm{~m}$ in diameter located $22.5 \mathrm{~m}$ from the center of the reactor where required gamma doses could not exceed $5 \mathrm{x}$ $10^{5} \mathrm{rad}$ and the fast neutron ( $1 \mathrm{MeV}$ equivalent) fluence could not exceed $1 \times 10^{13} \mathrm{n} / \mathrm{cm}^{2}$ over a 7 year operating life. These are representative values for protection of near-term electronics and not for biological protection.

For liquid metal cooled reactors, shield masses were estimated using ALKASYS-PC logic, which is based on Carlson (1985), Engle (1971), and Robinson (1996). For gas-cooled reactors, shield masses were scaled from the Enabler NERVA Derivative design. In that study, shield masses were based on a gamma dose of only $5 \mathrm{rad} / \mathrm{yr}$ at a distance of $100 \mathrm{~m}$ from the reactor. Polynomial-interpolation of published data for powers around $15 \mathrm{MW}_{\mathrm{e}}$ was used to scale to $15 \mathrm{MW}_{\mathrm{e}}$ under those same constraints. The resulting shield mass was $11,100 \mathrm{~kg}$. We used $1 / \mathrm{r}^{2}$ scaling on dose to relocate the protected area from $100 \mathrm{~m}$ to the $22.5-\mathrm{m}$ position and the logic for shield thickness determination in ALKASYSM to scale from the shifted Enabler design dose to the reference doses. We then scaled for reactor size variations with reactor volume to the $2 / 3$ power.

Thermal radiators in both system classes were assumed to have an areal mass density of $6 \mathrm{~kg} / \mathrm{m}^{2}$ of projected area. That is an improvement over the value of $20 \mathrm{~kg} / \mathrm{m}^{2}$ typically found in ALKASYSM results but consistent with the 6 $\mathrm{kg} / \mathrm{m}^{2}$ value used in GRC Brayton system analyses and in the SP-100 design. Two-sided radiators were assumed. We included secondary radiators for both system types to provide cooling for the shield ( $1 \%$ of reactor thermal power) and the alternator (assumed 95\% efficient).

Masses for the PMAD system, sometimes referred to as the power conditioning system, were assumed to be the same for both systems at $15,106 \mathrm{~kg}$, as used in the GRC analyses. That mass includes cooling for PMAD components.

We assumed as a baseline that both system types used four turbine/generator sets, though examination of a twoturbine set was performed for the Rankine system. Particularly for the Brayton systems, the ability of advanced 
turbines to accommodate turbine inlet temperatures was assumed, acknowledging severe technical challenges exist there.

For other components, masses found by the GRC Brayton analysis were assumed for Brayton systems, and those generated by ALKASYSM were accepted for the Rankine systems. The ALKASYSM results are inherently more conservative than those used in the GRC analyses.

\section{MODELING ASSUMPTIONS}

Assumptions beyond those mentioned above were required in the modeling analyses performed. These assumptions used are believed to be reasonably representative of current state-of-the-art or that which could be achieved through ambitious development in the next decade. They are listed in detail in Longhurst (2001b).

\section{RESULTS}

Results of calculations performed to evaluate the overall specific mass $\left(\mathrm{kg} / \mathrm{kW}_{\mathrm{e}}\right)$ for the two configurations chosen as baseline cases are shown in Table 2. Those cases were (1) direct heated gas using NERVA Derivative reactor technology for the Brayton system, and (2) lithium-cooled SP-100 reactor technology with potassium as the working fluid in a Rankine system having a condenser temperature of $800 \mathrm{~K}$.

TABLE 2. Parameter Comparison For The Two Baseline Comparison Cases.

\begin{tabular}{lcc}
\hline Parameter & Gas Brayton Baseline & Liquid Rankine Baseline \\
\hline Turbine inlet temperature $(\mathrm{K})$ & 1,640 & 1,260 \\
Reactor thermal power $\left(\mathrm{kW}_{\mathrm{t}}\right)$ & 61,579 & 59,108 \\
Thermal efficiency $(\%)$ & 24.4 & 25.4 \\
Reactor mass $(\mathrm{kg})$ & 6,648 & 14,654 \\
Shield mass $(\mathrm{kg})$ & 4,290 & 9,709 \\
Heat exchanger mass $(\mathrm{kg})$ & 0 & 2,254 \\
Turbine/generator mass $(\mathrm{kg})$ & 4,480 & 43,614 \\
Main radiator temperature $(\mathrm{K})$ & $746-541$ & 756 \\
Main radiator area $\left(\mathrm{m}^{2}\right)$ & 5,563 & 3,379 \\
Secondary radiator area $\left(\mathrm{m}^{2}\right)$ & 1,899 & 283 \\
Total radiator mass $(\mathrm{kg})^{\mathrm{a}}$ & 22,386 & 11,039 \\
Power conditioning mass $(\mathrm{kg})$ & 15,106 & 15,106 \\
Total mass $(\mathrm{kg})$ & 52,909 & 96,376 \\
Specific mass $(\mathbf{k g} / \mathbf{k W})$ & $\mathbf{3 . 5 3}$ & $\mathbf{6 . 4 3}$ \\
\hline
\end{tabular}

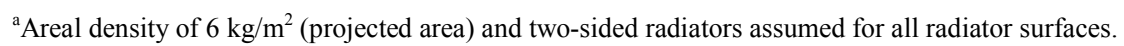

The main contributors to the disparity in masses for these two cases are the great differences in turbine/generator mass and reactor and shield mass. Much of the reason for these mass differences lies in the relative conservatism of the ALKASYSM design algorithm and the aggressive nature of the NERVA Derivative design. Probably, the liquid metal cooled reactor could be lighter than predicted by ALKASYSM.

Other reasons for turbine/generator masse differences between these cases is the need for vapor-liquid separation equipment at one or more places in the Rankine turbine to keep the vapor quality in the turbine high and the need for greater robustness in the Rankine turbine because of liquid droplets when quality is less than unity. On the other hand, the Brayton system will require a compressor. For the Rankine system, the turbine outlet temperature and 
pressure are set by the condensing temperature for the working fluid. The turbine mass, and therefore system overall specific mass, is highly sensitive to radiator temperature, as will be discussed later.

To examine the realism of the turbine mass estimates, we compared the turbine/generator masses predicted by the GRC Brayton model and by the ALKASYSM code with data from General Electric Power Systems' large commercial turbine/generator sets (GE, 2001). The resulting plot is shown in Figure 1. The masses given in the GE data are for complete open cycle Brayton systems including turbines, generators, housings and structural supports, sitting on a pad. The logarithmic fit (line in Figure 1) gives a mass at $15 \mathrm{MW}_{\mathrm{e}}$ of $108,961 \mathrm{~kg}$, while the mass predicted by ALKASYSM for condensing temperature of $800 \mathrm{~K}$ is $43,614 \mathrm{~kg}$. The mass predicted by the GRC Brayton model (see Table 2) is 4,480 kg, substantially below either of those values.

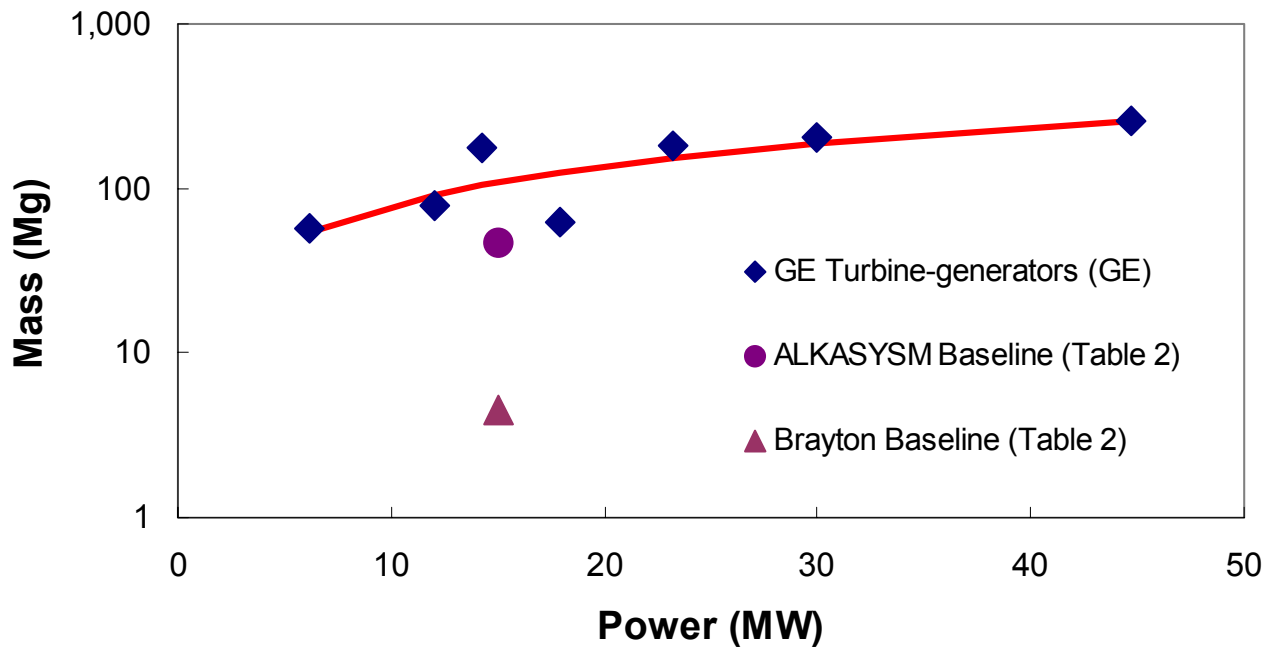

FIGURE 1. Comparison of Mass Estimates for Baseline Turbine Generator Cases (Table 2) with Commercial Turbine-Generator Masses.

A further datum for comparison is an estimate made by Morgan (1983) that a 10-MW $\mathrm{MW}_{\mathrm{e}}$ Brayton power conversion system would have a mass of about 25,800 kg. The fit in Figure 1, which would be expected for ground-based commercial systems, gives 79,505 $\mathrm{kg}$ for $10 \mathrm{MW}_{\mathrm{e}}$, more than three times the value of Morgan (1983). The estimate of Morgan (1983) for a liquid-metal Rankine power conversion system is 33 percent larger than for a Brayton system, reflecting greater complexity.

The turbine/generator mass values of Morgan (1983), scaled to $15 \mathrm{MW}_{\mathrm{e}}$ using the log-log fit of Figure 1, are $35,359 \mathrm{~kg}$ for the Brayton system and 47,008 $\mathrm{kg}$ for the Rankine system. The latter number is surprisingly close to the ALKASYSM prediction of $43,614 \mathrm{~kg}$. If we used the 35,359-kg value for the baseline Brayton system, its overall specific mass would increase from 3.53 to $5.59 \mathrm{~kg} / \mathrm{kW}_{\mathrm{e}}$.

We now consider individual results for the two system classes separately to show the effect of various parameter changes on the system specific mass.

\section{Brayton Systems}

Table 3 shows results for the Brayton power systems. Data in the upper part of the table are from GRC while data for reactor, shield, radiators, and total masses are from INEEL scaling. At the bottom is the resulting system specific mass.

In analyzing these data, it is no surprise that the configuration with the highest turbine inlet temperature $\left(\mathrm{UO}_{2} / \mathrm{ZrC}\right.$, $2100 \mathrm{~K}$ ) has the lowest specific mass and vice versa. The highest specific mass shown is the one for which the 
TABLE 3. Results from Glenn Research Center (Mason, 2001) and INEEL Analysis of Brayton Power Systems.

\begin{tabular}{|c|c|c|c|c|c|c|}
\hline Configuration (Table 1) & $\mathrm{UC2} / \mathrm{NbC}$ & $\begin{array}{c}\mathrm{UC2} / \mathrm{NbC} \\
\text { IHX }\end{array}$ & $\mathrm{UC2} / \mathrm{ZrC}$ & $\mathrm{UO2} / \mathrm{SiC}$ & $\mathrm{UO2} / \mathrm{ZrC}$ & $\begin{array}{l}\text { UN/Nb- } \\
1 \mathrm{Zr} / \mathrm{Li}\end{array}$ \\
\hline Turbine inlet temp (K) & 1,640 & 1,640 & 1,920 & 1,520 & 2,100 & 1,350 \\
\hline Thermal power $\left(\mathrm{kW}_{\mathrm{th}}\right)$ & 61,579 & 61,579 & 54,283 & 61,579 & 50,614 & 75,281 \\
\hline Compressor pressure ratio & 2 & 2 & 2.2 & 2 & 2.3 & 1.9 \\
\hline Turbine temperature ratio & 3 & 3 & 3.3 & 3 & 3.5 & 2.7 \\
\hline Thermal efficiency (\%) & 24.4 & 24.4 & 27.6 & 24.4 & 29.6 & 19.9 \\
\hline Heat exchanger mass $(\mathrm{kg})$ & 0 & 789 & 0 & 0 & 0 & 844 \\
\hline Turbine/generator mass (kg) & 4,480 & 4,480 & 4,210 & 4,477 & 4,091 & 4,769 \\
\hline PMAD mass $(\mathrm{kg})$ & 15,106 & 15,106 & 15,106 & 15,106 & 15,106 & 15,106 \\
\hline Main radiator area $\left(\mathrm{m}^{2}\right)^{\mathrm{a}}$ & 5,563 & 5,563 & 3,294 & 7,639 & 2,502 & 11,232 \\
\hline Secondary radiator area $\left(\mathrm{m}^{2}\right)^{\mathrm{a}}$ & 1,899 & 1,899 & 1,798 & 1,899 & 1,747 & 2,090 \\
\hline Radiator Mass $(\mathrm{kg})^{\mathrm{b}}$ & 22386 & 22386 & 15276 & 28614 & 12747 & 39966 \\
\hline Reactor Mass (kg) & 6,648 & 6,648 & 7,000 & 5,932 & 7,209 & 6,741 \\
\hline Shield Mass (kg) & 4,290 & 4,290 & 4,440 & 3,976 & 4,528 & 4,330 \\
\hline Total Mass (kg) & 52,909 & 53,699 & 46,032 & 58,105 & 43,682 & 71,756 \\
\hline Specific Mass $\left(\mathrm{kg} / \mathrm{kW}_{\mathrm{e}}\right)$ & 3.53 & 3.58 & 3.07 & 3.87 & 2.91 & 4.78 \\
\hline
\end{tabular}

${ }^{\mathrm{a}}$ Total radiating area, 2 -sided radiator assumed.

${ }^{\mathrm{b}}$ Radiator areal density of $6 \mathrm{~kg} / \mathrm{m}^{2}$ based on projected area assumed throughout.

reactor is cooled with lithium followed by a liquid-to-gas heat exchanger. It generates the most thermal power and has by far the largest radiator area because of the low temperature as well as the high power. Figure 2 shows graphically the relationship of the various mass components to turbine inlet temperature. Clearly, the greatest contributor to reduced system mass would be reduction in radiator mass.

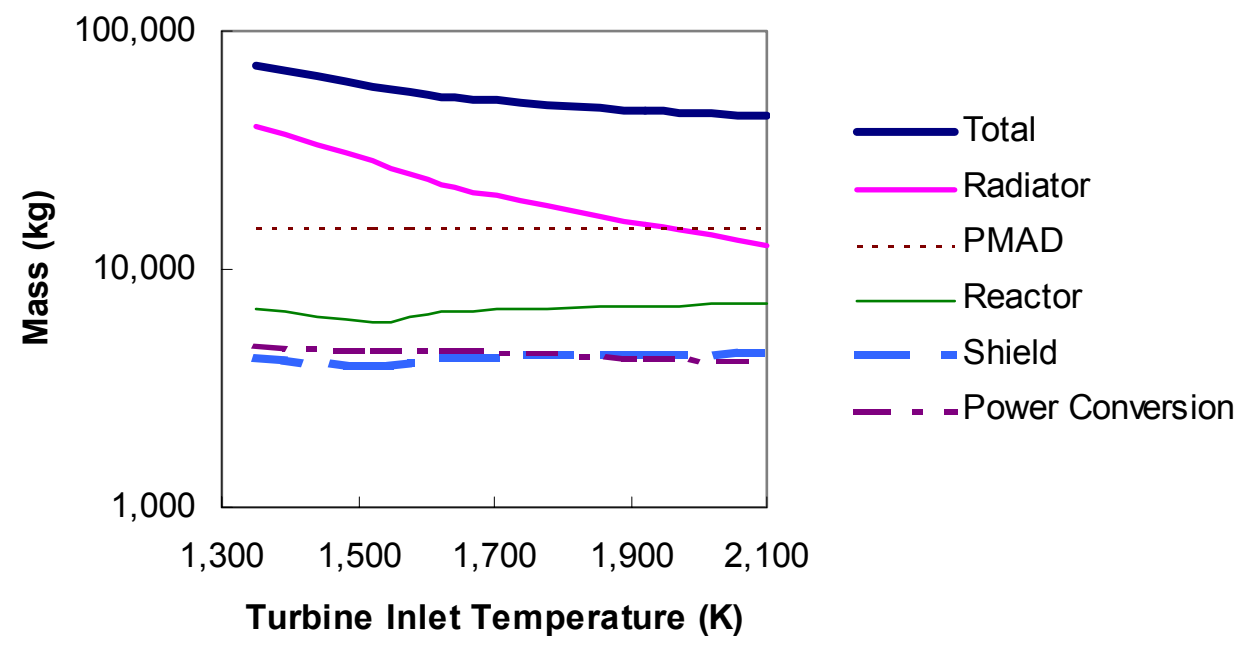

FIGURE 2. Brayton System Specific Mass Variation with Turbine Inlet Temperature. 


\section{Rankine Systems}

A number of analyses were performed for Rankine systems. Table 4 is similar to Table 3, showing corresponding data for the assumption of $800 \mathrm{~K}$ condensing temperature. Turbine inlet temperatures were reduced to make the reactor outlet temperatures 1,350 and $1,500 \mathrm{~K}$, respectively. Note that changing from lithium to gallium in the primary circuit and from potassium to sodium in the secondary each result in an increase of system specific mass.

TABLE 4. Results for Various Rankine Cycle Configurations Assuming 800-K Condenser Temperature for Main Radiator and $600 \mathrm{~K}$ for Low-Temperature Radiator.

\begin{tabular}{|c|c|c|c|c|c|c|}
\hline Configuration (Table 1) & $\begin{array}{l}\text { UN/Nb- } \\
\text { 1Zr/Li-K }\end{array}$ & $\begin{array}{l}\text { UN/Nb- } \\
\text { 1Zr/Ga-K }\end{array}$ & $\begin{array}{l}\text { UN/Nb- } \\
\text { 1Zr/Li-Na }\end{array}$ & $\begin{array}{l}\text { UN/ASTAR } \\
\text { 811C/Li-K }\end{array}$ & $\begin{array}{l}\text { UN/ASTAR } \\
\text { 811C/Ga-K }\end{array}$ & $\begin{array}{l}\text { UN/ASTAR } \\
\text { 811C/Li-Na }\end{array}$ \\
\hline Turbine inlet temp (K) & 1,260 & 1,260 & 1,260 & 1,410 & 1,410 & 1,410 \\
\hline Thermal power $(\mathrm{kWt})$ & 59,108 & 59,108 & 62,026 & 49,819 & 49,819 & 49,436 \\
\hline Thermal efficiency (\%) & 25.4 & 25.4 & 24.2 & 30.1 & 30.1 & 30.3 \\
\hline Heat exchanger mass $(\mathrm{kg})$ & 2,254 & 3,296 & 1,205 & 868 & 960 & 493 \\
\hline PMAD mass (kg) & 15,106 & 15,106 & 15,106 & 15,106 & 15,106 & 15,106 \\
\hline Main radiator area $\left(\mathrm{m}^{2}\right)$ & 3,397 & 3,397 & 3,626 & 2,665 & 2,665 & 2,635 \\
\hline Secondary radiator area $\left(\mathrm{m}^{2}\right)$ & 283 & 283 & 289 & 264 & 264 & 263 \\
\hline Radiator mass $(\mathrm{kg})^{\mathrm{a}}$ & 11,039 & 11,039 & 11,746 & 8,789 & 8,789 & 8,696 \\
\hline Reactor mass (kg) & 14,654 & 42,496 & 15,313 & 11,691 & 35,092 & 11,612 \\
\hline Shield mass (kg) & 9,709 & 5,621 & 9,895 & 8,216 & 3,855 & 8,196 \\
\hline Turbine/Generator mass $(\mathrm{kg})$ & 43,614 & 43,614 & 292,801 & 57,820 & 57,820 & 468,938 \\
\hline Total mass $(\mathrm{kg})$ & 96,376 & 121,172 & 346,065 & 102,490 & 121,622 & 513,041 \\
\hline Specific Mass $\left(\mathrm{kg} / \mathrm{kW}_{\mathrm{e}}\right)$ & 6.43 & 8.08 & 23.07 & 6.83 & 8.11 & 34.20 \\
\hline
\end{tabular}

Several observations may be made from these data.

- Higher turbine inlet temperatures don't result in reductions in system specific mass, even though reactor mass is reduced by about one fourth.

- Sodium as the working fluid in the Rankine system increases the mass of the turbines by about seven times, but it has little effect on reactor mass. The increased turbine size is due in part to the much greater specific volume of saturated sodium vapor than saturated potassium vapor at the same temperature, nominally by a factor of four. Liquid sodium also exhibits nominally twice the viscosity of liquid potassium, though it has a higher specific heat and thermal conductivity.

- Turbine/generator mass is dominant in all cases shown. We examined cases where only two turbine/generator units were assumed rather than four. System specific mass increased slightly with fewer units.

- Gallium in the primary circuit nominally triples the mass of the reactor over the lithium primary coolant case. There are also issues of corrosion and intersolubility with structural materials for gallium.

- All of the Rankine concepts considered here appear to be above the $5-\mathrm{kg} / \mathrm{kW}_{\mathrm{e}}$ goal on the range of desired specific masses. However, the estimates are probably pessimistic because of the conservative methodology used for Rankine systems. They will be reduced if turbine/generator masses can be reduced.

The temperature of the radiator and condenser has a strong influence on the system mass. Figure 3 shows how the various component masses vary as the temperature of the condenser is varied for Rankine-cycle cases where the reactor coolant exit temperature is $1,350 \mathrm{~K}$. Similar behavior is seen in all of the other Rankine-cycle cases examined. Note that the ordinate is logarithmic. Changing the condensing temperature above $800 \mathrm{~K}$ reduces system mass by about one fourth, but further condensing temperature increase appears to have little effect on overall system mass for the low-temperature near-term systems. For the higher-temperature advanced systems, increasing condensing temperature to $900 \mathrm{~K}$ dropped the system specific mass from 6.02 to $3.92 \mathrm{~kg} / \mathrm{kW}_{\mathrm{e}}$, largely through a reduction in turbine/generator mass. 


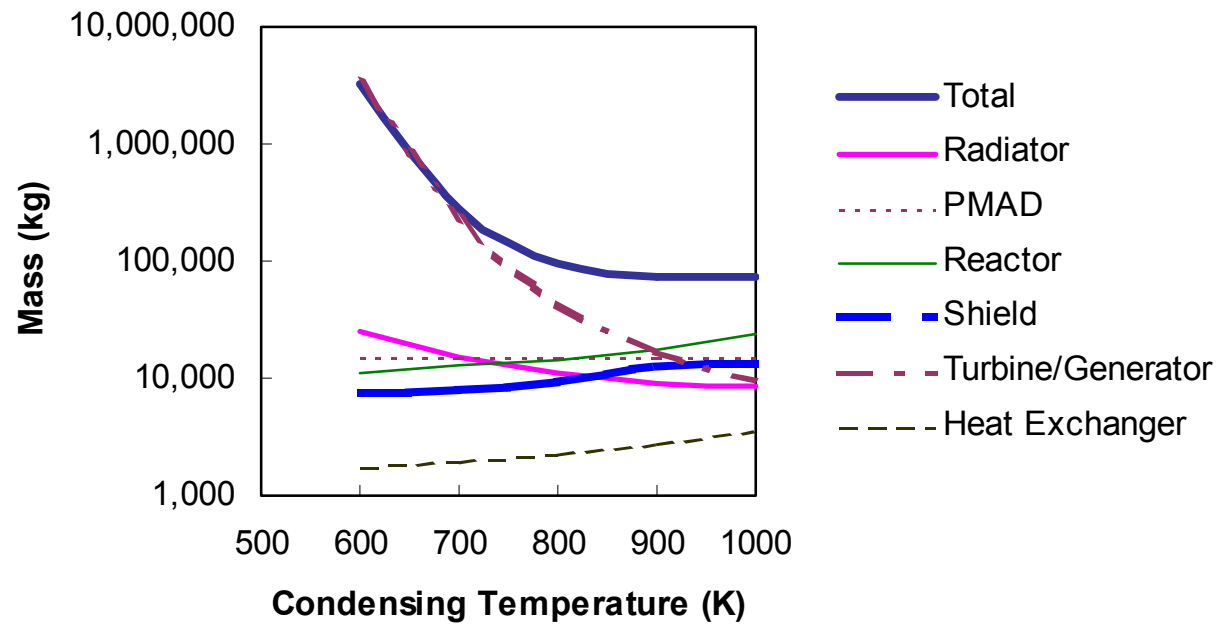

FIGURE 3. Variation in Mass of Rankine System Components with Variations in Condenser Temperature for Lithium Cooled Reactor with 1350-K Exit Temperature.

We present in Table 5 a comparison of the effects of changing to an electric motor on the baseline and "growth" configurations for the lithium-cooled potassium option. Assumed condenser temperature was $800 \mathrm{~K}$. It will be seen there that the addition of the motor results in a slight increase in reactor mass. The difference in specific mass is less than 1 percent.

TABLE 5. Effects of changing from a vapor-driven turbine to an electric motor for feed pump power are minimal.

\begin{tabular}{|c|c|c|c|c|}
\hline Configuration (Table 1) & $\begin{array}{l}\text { UN/Nb-1Zr/Li-K } \\
\text { Turbine }^{\mathrm{a}}\end{array}$ & $\begin{array}{l}\text { UN/Nb-1Zr/Li-Na } \\
\text { Electric Motor }\end{array}$ & $\begin{array}{l}\text { UN/ASTAR } \\
\text { 811C/Li-K } \\
\text { Turbine }^{b}\end{array}$ & $\begin{array}{l}\text { UN/ASTAR } \\
\text { 811C/Li-K } \\
\text { Electric Motor }\end{array}$ \\
\hline Turbine inlet temp (K) & 1,260 & 1,260 & 1,410 & 1,410 \\
\hline Thermal power $(\mathrm{kWt})$ & 59,108 & 59,122 & 49,819 & 49,813 \\
\hline Thermal efficiency (\%) & 25.4 & 25.4 & 30.1 & 30.1 \\
\hline Heat exchanger mass $(\mathrm{kg})$ & 2,254 & 2,606 & 868 & 1,082 \\
\hline PMAD mass (kg) & 15,106 & 15,106 & 15,106 & 15,106 \\
\hline Main radiator area $\left(\mathrm{m}^{2}\right)$ & 3,397 & 3,402 & 2,665 & 2,745 \\
\hline Secondary radiator area $\left(\mathrm{m}^{2}\right)$ & 283 & 283 & 264 & 264 \\
\hline Radiator mass (kg) & 11,039 & 11,056 & 8,789 & 9,027 \\
\hline Reactor mass (kg) & 14,654 & 14,657 & 11,691 & 11,690 \\
\hline Shield mass (kg) & 9,709 & 9,710 & 8,216 & 8,216 \\
\hline Turbine/Generator mass (kg) & 43,614 & 44,484 & 57,820 & 58,305 \\
\hline Total mass $(\mathrm{kg})$ & 96,376 & 97,619 & 102,490 & 103,426 \\
\hline Specific Mass $\left(\mathrm{kg} / \mathbf{k} W_{\mathrm{e}}\right)$ & 6.43 & 6.51 & 6.83 & 6.90 \\
\hline
\end{tabular}

A further comparison in Table 6 shows the effects of using direct boiling potassium in the reactors rather than a separate primary coolant, again for an assumed condensing temperature of $800 \mathrm{~K}$. Specific masses are a little lower for the direct boiling, high-temperature case due to lower reactor power allowing smaller components generally. Lower reactor thermal power is due to increased efficiency with higher turbine inlet temperature. Reactor mass is 
substantially increased for the $1,350-\mathrm{K}$ coolant exit temperature while it is reduced for the 1,500-K case upon changing to direct boiling. That is due to the difference in reactor configuration produced by the design algorithm, and in particular, in the mass of the pressure vessel, which is much larger for the 1,350-K case.

TABLE 6. Direct boiling of the working fluid gives marginally improved performance for the high-temperature case.

\begin{tabular}{|c|c|c|c|c|}
\hline Configuration (Table 1) & $\mathrm{UN} / \mathrm{Nb}-\mathbf{1 Z r} / \mathbf{L i}-\mathbf{K}^{\mathrm{a}}$ & $\begin{array}{l}\text { UN/Nb-1Zr/Li-Na } \\
\text { Direct Boiling }\end{array}$ & $\begin{array}{l}\text { UN/ASTAR } \\
\text { 811C/Li-K }^{b}\end{array}$ & $\begin{array}{l}\text { UN/ASTAR } \\
\text { 811C/Li-K } \\
\text { Direct Boiling }\end{array}$ \\
\hline Turbine inlet temp (K) & 1,260 & 1,350 & 1,410 & 1,500 \\
\hline Thermal power $(\mathrm{kWt})$ & 59,108 & 52,577 & 49,819 & 45,945 \\
\hline Thermal efficiency (\%) & 25.4 & 28.53 & 30.1 & 32.65 \\
\hline Heat exchanger mass $(\mathrm{kg})$ & 2,254 & 0 & 868 & 0 \\
\hline PMAD mass (kg) & 15,106 & 15,106 & 15,106 & 15,106 \\
\hline Main radiator area $\left(\mathrm{m}^{2}\right)$ & 3,397 & 2,883 & 2,665 & 2,361 \\
\hline Secondary radiator area $\left(\mathrm{m}^{2}\right)$ & 283 & 268 & 264 & 254 \\
\hline Radiator mass (kg) & 11,039 & 9,453 & 8,789 & 7,846 \\
\hline Reactor mass (kg) & 14,654 & 30,483 & 11,691 & 10,368 \\
\hline Shield mass $(\mathrm{kg})$ & 9,709 & 5,054 & 8,216 & 4,360 \\
\hline Turbine/Generator mass (kg) & 43,614 & 39,229 & 57,820 & 53,239 \\
\hline Total mass (kg) & 96,376 & 99,325 & 102,490 & 90,919 \\
\hline Specific Mass $\left(\mathrm{kg} / \mathrm{kW}_{\mathrm{e}}\right)$ & 6.43 & 6.62 & 6.83 & 6.06 \\
\hline
\end{tabular}

Another point is that none of the system radiators, either Rankine or Brayton, would fit into the launch bay of present-day lift vehicles without some ingenious packaging and deployment mechanisms.

\section{CONCLUSIONS}

The analyses conducted in this trade study compared specific masses for various configurations of gas-cooled reactors with Brayton cycle power conversion systems and liquid-cooled reactors having both Rankine and Brayton cycle power systems. The methodology employed took advantage of existing models for estimating some component masses for the respective systems. Reactor and shield masses for the liquid metal systems were generated by the ALKASYSM code while those of the gas reactor systems were scaled from Enabler NERVA Derivative reactor values.

Either power system option has the potential to approach the specific mass objective of $3-5 \mathrm{~kg} / \mathrm{kW}_{\mathrm{e}}$, but realization of that goal for either concept will require considerable effort. Gas-cooled Brayton cycle concepts examined appeared to fall within that band, while the liquid-cooled Rankine cycle systems appeared higher. Considering the more conservative design algorithms for the liquid-cooled Rankine concepts, expectations could be similar between the two systems. Brayton systems avoid the problems of two-phase flow in the microgravity environment of space.

We explored variations in Rankine system configuration including changing fluids and replacing the feed pump turbine in the Rankine configuration with an electric motor. Substituting electric motor driven feed pumps for turbine driven pumps slightly increased (less than 1 percent) system specific masses. Using direct boiling potassium instead of liquid lithium offered small (11 percent) reduction in specific mass for the advanced, high temperature system, but increased the specific mass for the nearer-term, lower-temperature case. Substituting gallium for lithium or sodium for potassium each resulted in much higher specific masses. Increasing condensing temperature from 800 to $900 \mathrm{~K}$ reduced system specific mass by about one fourth for Rankine systems, but there was little reduction at higher condensing temperatures for the near-term lower temperature system. There was a $30 \%$ improvement at the 
higher reactor operating temperatures of advanced systems. Going to lower condensing temperature drastically increased system specific mass.

In addition to reactor fuel development challenges, key technology issues include turbines that will withstand assumed inlet temperatures, and the ability to fit the large radiators required for this power level into launch vehicles.

\section{ACKNOWLEDGMENT}

The authors are indebted to Dr. Lee Mason of the NASA Glenn Research Center for computations of Brayton power conversion system component masses. This work was performed for the U.S. Department of Energy, Director for Nuclear Energy, Science and Technology under DOE Idaho Operations Office Contract DE-AC07-99ID13727.

\section{REFERENCES}

Carlson, D. E., A Parameter Study for the SP-100 Radiation Shield, SP TN 101, Los Alamos, NM, Los Alamos National Laboratory, 1985.

Chang-Díaz, F. R. et al., "The Physics and Engineering of the VASIMR Engine," in AIAA 2000-3756, 36 AIAA/ASME/SAE/ASEE Joint Propulsion Conference, Huntsville, AL, July 17-19, 2000.

Engle, Jr., W. W. et al., Optimization of a Shield for a Heat-Pipe-Cooled Fast Reactor Designed as a Nuclear Electric Space Power Plant, ORNL/TM-3499, Oak Ridge, TN, Oak Ridge National Laboratory, 1971.

General Electric Power Systems Internet site http://gepower.com/products/prod specs.htr., February 8, 2001.

General Electric Power Systems Internet site http://www.gepower.com/corporate/en_us/aboutgeps/ releases/20010919. pdf., October 7, 2001a.

Longhurst, G. R., "ALKASYS Code Adaptation," INEL/EXT-01-00539, Idaho Falls, ID, Idaho National Engineering and Environmental Laboratory, 2001a.

Longhurst, G. R., Schnitzler, B. G., and Parks, B. T., "Multi-Megawatt Power System Trade Study," INEEL/EXT-01-00913, Idaho Falls, ID, Idaho National Engineering and Environmental Laboratory, 2001b.

Longhurst, G. R., Harvego, E. A., Schnitzler, B. G., Seifert, G. D., Sharpe, J. P., Verrill, D. A., Watts, K. D., Parks, B. T., "MultiMegawatt Power System Concept Evaluation," INEEL/EXT-01-00938, Idaho Falls, ID, Idaho National Engineering and Environmental Laboratory, 2001c.

Mason, L. S., NASA Glenn Research Center, private communication, March 21, 2001.

Morgan, R. E. et al., "Comparison of High Power Nuclear Systems for Space Application," Proceedings of the $18^{\text {th }}$ Intersociety Energy Conversion Engineering Conference, Orlando, Florida, August 21-26, 1983, pp. 977-982.

Moyers, J. C. and Nichols, J. P., ALKASYS, A Computer Program for Studies of Rankine Cycle Space Nuclear Power Systems, ORNL/TM-10427, Oak Ridge, TN, Oak Ridge National Laboratory, 1987.

Pierce, B. L., "Application of the Enabler to Nuclear Electric Propulsion," Proceedings, Eighth Symposium on Space Nuclear Power Systems, Part One, Albuquerque, NM, January 6-10, 1991, pp. 379-384.

Robinson, R. A. et al., Brayton-Cycle Radioisotope Heat Source Design Study: Phase 1 (Conceptual Design) Report, ORNL/TM1691 (NASA CR-72090), Oak Ridge, TN, Oak Ridge National Laboratory, 1996, pp. 90-100.

Rutger, L. L. and Truscello, V. C., The SP-100 Power System," AIP Conference Proceedings No. 246, American Institute of Physics, 1992. 